\title{
INSIDER-OUTSIDER PHENOMENON IN TRADITIONAL DANCE RESEARCH IN INDIGENOUS COMMUNITIES
}

\author{
Ronald KIBIRIGE \\ Choreomundus - International Master in Dance Knowledge, Practice and Heritage \\ Uganda Folk Arts Research Organisation \\ 22988, Kampala, Kasangati-Gayaza R8, Uganda \\ E-mail: peaceafricachild@gmail.com
}

\begin{abstract}
Scholarly research in the field of traditional dance ${ }^{1}$ has been carried out under the umbrella of cultural studies that have been ignored in all academic circles in the East African states of Uganda, Kenya, Tanzania, and Rwanda. Until the late 1960s, there was no distinguished academic institution in the East African region that offered studies in dance. Although traditional dance plays a pivotal role in the execution of the day-to-day activities in many East African communities, less effort has been put into its development in form of research from within the region. Much of its sources today create concern due, but not limited only, to their scarcity, but also to the fact that outsiders from the dance traditions in question mostly author them, thereby creating a perennial outsider-researcher phenomenon. In this paper, I reflect on two traditional dance research experiences; In Transylvania - Romania in October 2013, and a comparatively longer experience of folk dancing in the different rural communities of Uganda in a quest to further understand the practical results of a field research in traditional dance that is rather dominated by dance researchers from outside that dance culture, and the influence of such research results to the bearers of the dance tradition.
\end{abstract}

Keywords: insider-outsider perspectives, Uganda, Transylvania, traditional dance

The notion of fieldwork in the academic realm has not only been accommodated and carried out by knowledge enthusiasts to enrich their scopes of work, but to also scientifically prove different phenomena in society. In the field of dance research in Eastern Europe, as Anca Giurchescu in Theory and Methods in Dance Research ${ }^{2}$ contends, field work is still the main method of research used by both anthropologists and choreologists despite the different approaches in regards to the way it is carried out. However, indigenous dance practices, like other traditional practices and rituals are best understood by their bearers

${ }^{1}$ By 'traditional' dance, I refer to the rural community dance forms, which are said to belong to the cultural fabric of the people in a said local community.

${ }^{2}$ Giurchescu - Torp 1991: 6. 
and practitioners. ${ }^{3}$ The lack of indigenous knowledge and understanding of a specific culture (dance culture inclusive) could rather deprive indigenous communities of consciously choosing the fate of their cultural history, as cultural norms and values are made prone to deconstruction and reconstruction. Contention that some indigenous communities may not have enough intellectual and academic competence to present written facts about their dance traditions from within their communities boosts the challenge of misrepresentation on the basis of fieldwork by outsider researchers. This phenomenon results into appropriation and reconstruction of dance cultures as Desmond Jane contends. ${ }^{4}$

In the Northern region of Uganda for example, there are un-imaginable cases of conditionality due, but not limited, to its political, social and economic state of affairs. Some cultural activities, for example $W a n g u^{5}$, could not be carried out due to preoccupations and conditions of war. This state of affairs has created panic, anxiety, intrigue and community disorientation, much of which if not checked would trigger sudden changes in the socio-cultural patterns and further hinder cultural development and continuity. The abduction of children, their turn into child soldiers, and the subsequent displacement from their families, has indeed created a strong cultural disorientation that could be difficult to comprehend, especially by the youth and the children today.

According to Judith Hanna, "music and dance in African communities presided over most, if not all the human activities in a given human life span". 6 Although Hanna's argument perhaps gives a generalized view of the music and dance cultures of a continent with so many different peoples, it points out the possible challenge of presenting traditional dance fieldwork findings without dwelling on a detailed understanding of such cultures. For a seven-day field trip to a given new community, one can think and theorise depending on their different levels of understanding. However, without specific insider knowledge, familiarity to the community, and revered experience, one would only give generalised overview accounts of his rather short experience - a fact that has characterised some traditional music and dance research findings from many indigenous communities, especially in countries euro-centrically branded to be "developing countries". Moving from the holistic regard of a dance event as experienced on the fieldwork trip to Transylvania, to a more specific practice and living of one of the movement patterns during the course of the fieldwork enhances the conception of understanding a movement pattern and all its predicaments. The latter includes living in that specific moment when one performs a specific dance movement, and could perhaps give a different perception on the essence of fieldwork. In their article, Eliciting the Tacit ${ }^{7}$, Georgiana Gore et al. discuss approaches to extract tacit knowledge from informants. This article brings to light what makes explicit interviews productive tools for the study of practical knowledge. For field researchers who work in communities where dance knowledge cannot easily be verbalized, and where the prescribed time for research is relatively short for the researcher to learn the local lan-

\footnotetext{
${ }^{3}$ Also see Grau 1994: 89.

${ }^{4}$ Desmond 1993: 38-41.

${ }^{5}$ Wang $u$ is a traditional advisory session administered by a group of elders to the children and the youth, around an outside fire place on a calm evening.

${ }^{6}$ Hanna 1965: 13.

${ }^{7}$ Gore - Rix-Lievre - Wathelet - Cazemajou 2012.
} 
guage of the bearers of the dance traditions, explicit interviews could be used. However, the case of a local fieldwork experience, which is even shorter so that explicit interviews cannot be carried out, closes in to my short experience in Transylvania, and highlights the gist of this paper. For a traditional dance practitioner living in both rural and urban communities in a multi-ethnic African nation, a short field experience to a Gypsy community creates questions related to the commonly understood meaning of fieldwork for an outsider of a specific dance culture. With the time spent in the field notwithstanding, dance cultures are best understood by their bearers. A researcher would argue that the snapping of the fingers and clapping of the hands in a Romanian traditional dance as shortly observed in the Gherla village of Transylvania helps the dancer to regulate his rhythm and the dance beat, or that the slapping of the lower leg in a Romanian Gypsy dance has no specific meaning attached to it. Indeed, these sentiments may be the information obtained from the informants in the fieldwork. But, when I asked one Hungarian traditional dancer what he feels when they dance the same dance without snapping their fingers, he said, "it does not feel the same way as it is when we dance while snapping". ${ }^{8}$

The acts of snapping, clapping, and slapping during the dance may or may not have meaning emic to the dancers and the dancing community. However, what is it that they feel? How and why do they feel that way? Is it the same feeling from one dancer to another in that community? How can a researcher from a different cultural background and orientation genuinely come to the understanding of such a feeling, and how can a random reader from within or outside that community come to trust just a written text to be genuine?

In the social performance of Myel Bwola from the Acholi sub-region of Uganda, there is literally no audience separated from the performer. When the drum sounds, accompanied with folk singing, dancing definitely follows. However, when the would-be audience feels like dancing at any time during the performance of the dance, they spontaneously start dancing. Similarly, one would ask: what is it that propels the would-be audience to get up and dance? How can an outsider researcher, with the time spent in field notwithstanding, genuinely explain this phenomenon, without living this moment in the performance?

On a dance event organised during the fieldwork trip in the Gherla community in Transylvania, dancers from the communities danced. Difficult as it was to differentiate among the dancers and musicians who were or were not professionals, the community members sometimes joined to dance too. Additionally, in reference to a research methodological tool well known as participant observation, some of the researchers joined to dance too. As difficult as it is to understand the reason and the influence of their participation, some tried to get a feeling of some simple movements. Some tried to get into short processes of learning some intriguing dance movements, the latter of which could be notated (see Figure 2). In a small group of three, some researchers on this dance event made an attempt to understand the relationship between the musicians and dancers, and vise-versa (see Figure 1) through observing the dancers, listening to the accompanying traditional music, in addition to conducting some group interviews with traditional musicians.

${ }^{8}$ Personal interaction in the fieldwork. 


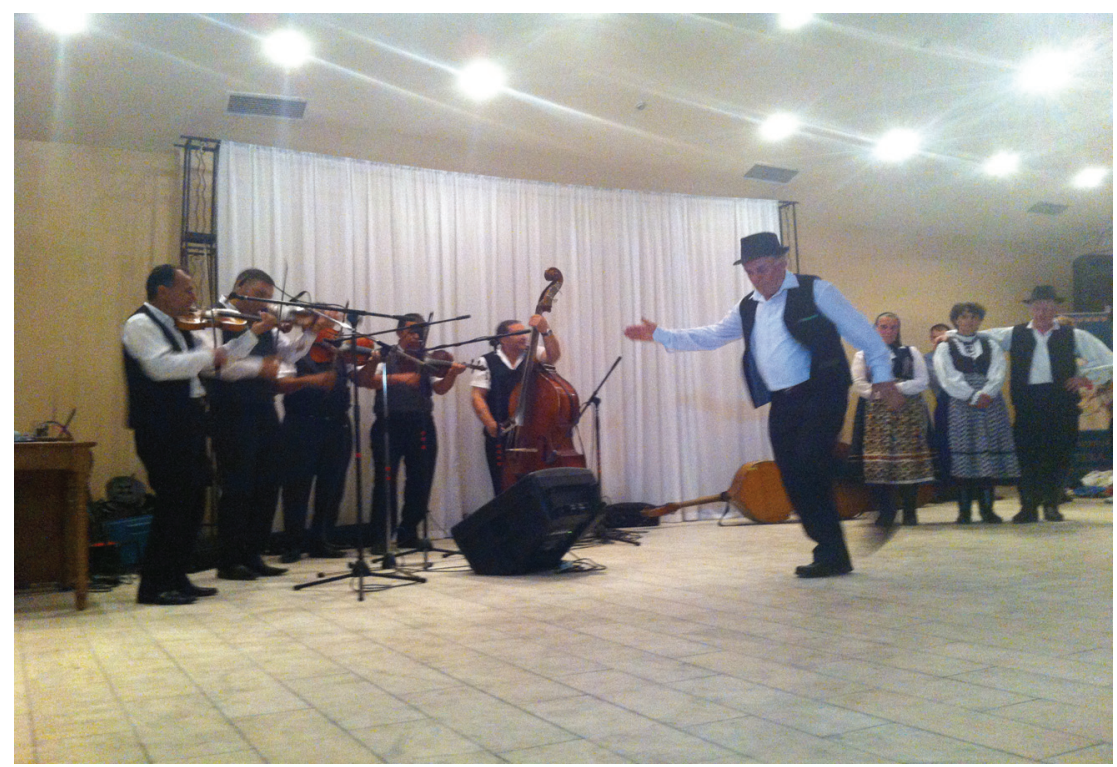

Figure 1. A traditional solo dancer and musicians from the village of Frata at the Mezóség Dance Festival in Gherla - Transylvania (Photograph by Ronald Kibirige $-27^{\text {th }}$ October 2013)

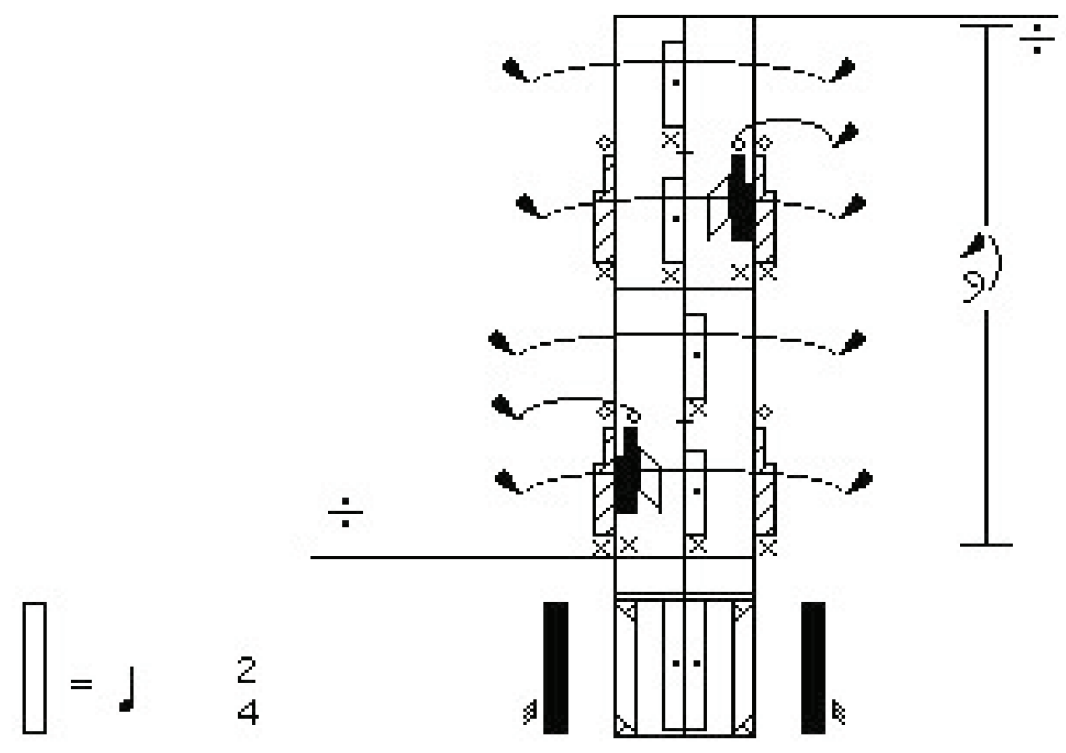

Figure 2. Notation of a traditional dance movement pattern from the Mezőség area in Transylvania 
Perhaps the wild question of how the outsider researchers felt when they danced, or rather when they tried to assimilate to the situation by trying to dance still lingers in the back of my head.

Figure 2 is a clear manifestation of the researcher's interpretation of how the community executed that movement pattern. However, if a community dancer, or member of this community understood the system of notation used in Figure 2 to the same level as the researcher in question, is this how they would have notated this movement pattern? In reference to this short experience, one would wonder how long it would take an outsider researcher of such a dance tradition not only to assimilate, and mechanically execute the movement, but rather live and perform this movement unconsciously. To become one with the movement would rather be an ambiguous statement to state at the least, but to immerse one's self into it is another aspect to ponder. As Egil Bakka states, "the ultimate flow of experience, which a dancer is searching for, takes over, when he or she let go of all preoccupations". ${ }^{9}$ Does this phenomenon require one to denounce all his cultural orientation beforehand in order to perform such a movement without outside culturally orientated preoccupations? Can an outsider with either lose or vivid dance knowledge genuinely and practically achieve this status?

In a bid to elaborate on Labanotation as a tool in dance research, János Fügedi, in his article 'Movement Cognition and Dance Notation' states that: "The vast majority of our movements are acquired by learning; especially great effort is spent on movement skills such as dancing-still these movements are performed without consciousness. Because of this automated un-consciousness one meets great difficulties in verbally formulating the characters, structure the manner of exact performance of the movements that is including them in cognitive process." 10

Indeed, it can be argued that most of the genuine movements in traditional dances are performed un-consciously in a sense that the performers do not necessarily have to think much about choreographic structures, form, etc. They live the dancing and let it happen as it comes to them with relatively no preoccupations. However, the question of how much the researcher has to give up in order to genuinely achieve this status to truly experience this moment in dancing is still a force to recon with for dance researchers. In the case of traditional folk dance research in Uganda, the insider-outsider phenomenon can be put to the open. In the early 1880 s when missionary work started, many communities were in complete illiteracy. As Theresa Buckland affirms, "traditions call attention to the inter-relationship between the past and the present and locate local cultural continuity".11 Additionally, what is written today becomes history tomorrow. However, it is important for one to understand who writes this history in order not to make mistakes that cannot or would be very difficult to change. However, as Ugandan historian Ssemakula Kiwanuka ${ }^{12}$ and dance anthropologist Georgiana Gore ${ }^{13}$ contend, one of the chief challenges confronting indigenous dance practices in Uganda, East Africa and Africa in general is the lan-

\footnotetext{
${ }^{9}$ BAKKA - Gore 2007: 4.

${ }^{10}$ FÜGEDI 2003: 393-394.

${ }^{11}$ Buckland 1994: 51.

${ }^{12}$ Kiwanuka 1968: 27.

${ }^{13}$ Gore 1983: 62.
} 
guishing state of its resources. Much of the present sources are oral traditions, which have neither been recorded nor studied. Moreover, the few researchers ${ }^{14}$ who have attempted to write about dancing in East Africa have focused on cultures as a whole. There has been comparatively less (if any) research on indigenous dance practices in Uganda. The few written records on traditional folk dance that exist are from the early 1950s, and were mostly written by outsiders to the traditions who had limited indigenous knowledge about these cultures. This has not only characterised the content of these written records to have blurred origins, but has also contributed to their scarcity in many communities, amongst the children, and the youth. In consideration of this situation especially in many Ugandan communities, the system of transfer of traditional dance knowledge from one person to another is mostly oral.

Depending on the focus and purpose of the research, it is a challenge for dance researchers carrying out dance research in communities and dance cultures that are not their own, especially amongst indigenous communities. A specific focus may perhaps help the researcher direct or redirect their efforts to concentrate on a given aspect, but the general perception and principle of dance fieldwork that may involve presentation of findings in the form of texts, video, audio, and/or audio-visual recordings could stand to be particularly challenging in this regard, as inaccuracy in interpretation can severely affect the history of such communities.

\section{LITERATURE}

BAKKA, Egil - GoRe, Georgiana

2007: Constructing Dance Knowledge in the Field: Bridging the Gap between Realization and Concept. In: Re-thinking Practice and Theory. Proceedings of the Thirtieth Annual Conference. Center National de la danse, Paris, 21-24 June 2007, Society for Dance History Scholars.

Buckland, Theresa J.

1994: Embodying the Past in the Present: Dance and Ritual. Proceedings of the 18th Symposium of the Study Group on Ethnochoreology. International Council for Traditional Music, August 9-18, 1994, Skierniewice, Poland. Warszawa: Instytut Sztuki PAN.

Desmond, Jane C.

1993-1994: Embodying Difference: Issues in Dance and Cultural Studies. Cultural Critique 26(Winter), $33-63$.

FüGEDI, János

2003: Movement Cognition and Dance Notation. Studia Musicologica Academiae Scientiarum Hungaricae 44(3-4), 393-410.

Giurchescu, Anca - Torp, Lisbet

1991: Theory and Methods in Dance Research: A European Approach to the Holistic Study of Dance. Yearbook for Traditional Music 23, 1-10.

GoRe, Georgiana

1983: Traditional Dance in West Africa. In: Adshead-Lansdale, Janet - Layson, June (eds.): Dance History: An Introduction. London-New York: Routledge.

Gore, Georgiana - Rix-Lievre, Géraldine - Wathelet, Oliver - Cazemajou, Anne

2012: Eliciting the Tacit: Interviewing to Understand Bodily Experience. In: SkInNER, Jonathan (ed.): The Interview: An Ethnographic Approach. London: Berg, 124-142.

${ }^{14}$ Mitchell 1956; Ranger 1975. 
Grau, Andrée

1994: Ritual Dance and 'Modernisation': The Tiwi Example. In: Dabrowska, Grazyna (ed.): Dance Ritual and Music: Proceedings of the 18 th Symposium of the Study Group on Ethnochoreology. International Council for Traditional Music, August 9-18, 1994, Skierniewice, Poland. Warszawa: Instytut Sztuki PAN, 89-96.

Hanna, Judith L.

1965: Africa’s New Traditional Dance. Ethnomusicology 9(1), 13-21.

Kiwanuka, M. S. M. Semakula

1968: The Empire of Bunyoro Kitara: Myth or Reality? Canadian Journal of African Studies / Revue Canadienne des Études Africaines 2(1), 27-48.

Mitchell, J. Clyde

1956: 'The Kalela Dance': Aspects of Social Relationships among Urban Africans in Northern Rhodesia. In: Rhodes-Livingstone Institute Papers No.27. Manchester: Manchester University Press.

RANGER, Terence O.

1975: Dance and Society in Eastern Africa, 1890-1970. London: Heinemann. 